\title{
USE OF INDIVIDUAL PROTECTION EQUIPMENT IN CIVIL CONSTRUCTION
}

\author{
Williams Ícaro Miranda da Silva ${ }^{1}$, David Barbosa de Alencar ${ }^{2}$ and Jorge de Almeida Brito Junior ${ }^{3}$
}

1,2,3 Blauro Cardoso de Mattos Higher Education Institute - FASERRA. Manaus-Amazonas, Brazil.

Email: williams.icaro@gmail.com, david002870@hotmail.com,jorgebritojr@gmail.com

Received: Aug 14th, 2019

Accepted: Aug 30th, 2019

Published: December 02 ${ }^{\text {th }}, 2019$

Copyright (C2016 by authors and Galileo Institute of Technology and Education of the Amazon (ITEGAM).

This work is licensed under the Creative Commons Attribution International License (CC BY 4.0).

https://creativecommons.org/licen ses/by/4.0/

Opean Actest:

\begin{abstract}
The use of Personal protective equipment (PPE) is extremely essential for any activity that is prone to occupational hazards and / or illnesses that could threaten the safety and health of the worker. The construction market has grown abundantly in recent years, and consequently the risk of accidents in this work environment as well. There are several reasons for this growing increase in accidents at work, among them is the Contracting Company that does not provide correctly the equipment of personal protection for its employees and the lack of commitment and interest of the employees in the use of protective equipment. The objective of this study is to evaluate the use of individual protection equipment in the construction company in a given service rendering, which includes the construction of reinforced concrete wall and drainage network installation, observing the methods used for adhesion and control of the use of PPE. Although the work is short-term and the accident risk is high, in the course of the work up to the date of delivery, a satisfactory result was obtained both for the Company and for the employees involved in the activities, as it had no accident of job.
\end{abstract}

Keywords: Individual Protection Equipment; Contributors; Accident.

\section{INTRODUTION}

The terms of safety at work is an item of great importance in all the industrial activity, aiming to decrease the consequences that cause dangers to labor activities. This occurred in a natural way, since human beings are possessed the instincts of caution of life. And today, as humans most of the time they are inserted inside of organizations that generally amid labor, are the companies, it is natural for people to seek to protect themselves in daily activities, however, there are always some people who do not give due weight to your own health and safety.

Safety at work can be understood as the sets of measures that are adopted to minimize accidents at work, occupational diseases, as well as protect the integrity and the ability to work of the employee, within some measures we have the collective and individual protection equipment. In the field of civil construction, security depends almost exclusively of your labor, because most of the time the developer receives the individual protection equipment and it turns out your trivializing use by lack of knowledge and trust other in your belief that the accident will never happen yourself, the fact of relying on directly from the developer should cooperate for a better security management in companies, but it is one of the economic sectors with the highest rate of accidents.

In this context, this study aims to demonstrate the importance and necessity of the use of personal protective equipment for employees in construction, to reduce the number of accidents, and, in addition, to sensitize employees to the same are responsible for your safety and your coworkers and also assist in the identification of occasions that can give risks and thus help correct the errors.

\section{DEVELOPMENT}

According to the [1], for the purposes of good job of NR, considered personal protective equipment-PPE, any device or product of single use used by the worker, for the protection of risks likely to threaten the safety and health at work. The personal protective equipment, national or imported manufacturing, may only be marketed with the certificate of approval-CA, carried out by the competent national agency for safety and health at work of the Ministry of labor and employment [1]. 
The individual protection equipment (PPE), can be divided in terms of body area to protect: head protection (helmet), hearing protection (ear plugs or ear protectors noise and caps), respiratory Protection (masks, devices filters own against every kind of air contaminant: gases, aerosols), ocular and facial Protection (goggles, face shields and masks), hand and arm protection (gloves, made in various materials and sizes as the risks against which you want to protect: mechanical, chemical, biological, thermal or electric), protection of feet and legs (shoes, shoes, boots, sneakers, appropriate for the risks against which you want to protect: mechanical, chemical, electrical, and fall), protection against falls (belts parachute systems security, belts) [2].

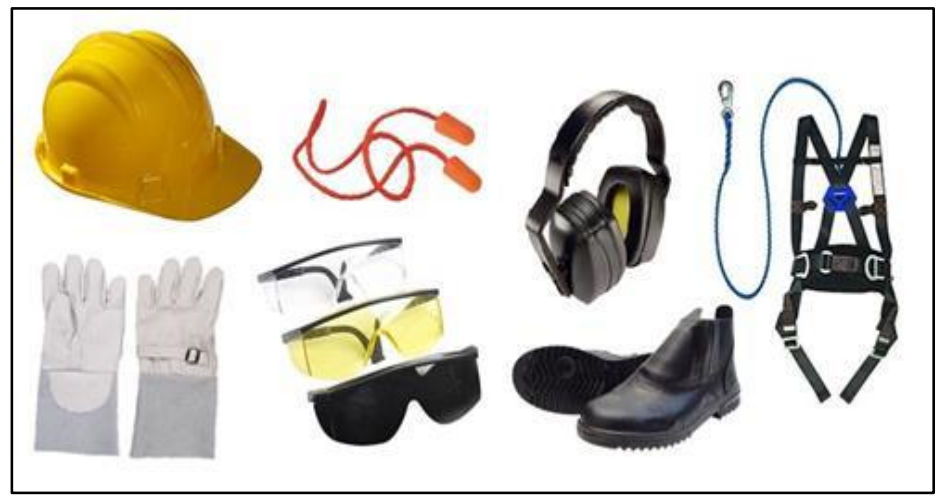

Figure 1: Personal Protective Equipment. Source: [2].

Figure 1 presents some PPE's used to protect the worker's body area, shows the helmet, earplugs, earmuffs, seat belts, gloves, goggles and boots roughing of security.

The construction environment makes use of these groups of PPE's, and most of those described in NR-6 because it is a sector which brings together activities focus on services that present risks due to contact with water, heights, with electricity, in addition to the risks the works of demolition, excavation, masonry, flooring and coatings application, carpentry and metalwork that encompass the activities developed in construction [3].

The use of this type of equipment should only be done where it is not possible to take measures to eliminate the risks of the environment in which it develops the activity, i.e. when the collective protection measures are not viable, efficient and sufficient for mitigation of risks and do not offer complete protection against the risks of industrial accidents and/or occupational diseases and work. As the CPE does not depend on the will of the worker to suit your purposes, this has a higher preference for use of PPE since collaborates in the process while minimizing the negative effects of a working environment that presents a number of risks to the worker. When employees do not use the correct PPE's, the risk of an accident is drastically high, most of the time the accident ends up causing personal injury or functional disturbance may cause death, temporary or permanent reduction or loss, the ability to work.

Collective protection equipment is used in the workplace for security protection while a group of people perform certain task or activity, as an example of collective protection equipment (CPE) we can mention: Protection networks, security flags (such as plates and warning signs, or color), fire extinguishers, Wash eyes, safety showers, Fans, first-aid Kit. In Figure 2 are explicit some of these items used in collective protection of the worker.
At the construction site, the protection of all employees is the application of the CPE, which "are performances, equipment or information that serve as obstacle between the risk of accident and the workers. In a more open vision, are all security measures adopted in a work to protect one or more persons. " [4].

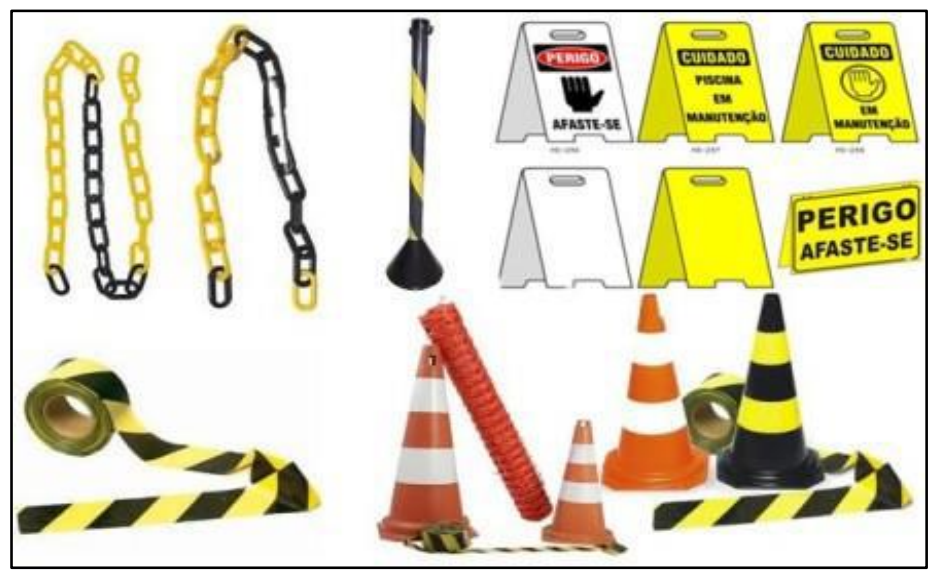

Figure 2: Collective Protection Equipment. Source: [3].

As the [1] about the availability of personal protective equipment, determines that the undertaking is obliged to equip employees for free, PPE according to the risk present in the activity developed by the employee, in great condition and functioning, in the following situations: the whole time as the action) of a general nature not provide full protection against the risks of industrial accidents or occupational diseases and work; b) during the time that collective protection measures are being implemented; and, c) to meet emergency situations [1].

One of the tasks required by NR-6 [1], as the responsibility of the employee fit to even obey the following recommendations: use personal protective equipment only for the purpose of protecting your health and safety; keep and keep saved; inform along the company and/or person in charge about any changes that make the use of inadequate PPE and meet properly the employer's determinations and training under the personal use.

\section{METHODOLOGY}

The location of the case study is in a small business that will hold a service of building wall in reinforced concrete and installation of drainage network, according to table II of NR 4specialized services in safety engineering and occupational medicine $(104,000-6)$ - [5], the service to be provided has the degree of risk 4 . The total number of employees is less than 50, so you do not need the need for security and engineer or occupational physician, however, the contractor has provided a security technician at work to follow the activities to be performed to ensure the integrity of the company and protect employees from the risk of accidents.

In principle it was asked of service provider contracts for labor and occupational health certificate to all employees (ASO), then was asked to plug individual protection equipment to ensure that employees would be getting the PPE' $s$ according to each activity to be performed so that the supervision charged using the same, PPE is of paramount importance to have control in the management of the equipment, an ideal PPE contains her information from each item of PPE available, certificate of 
approval (CA) informed, validity, the amount received by the employee, the employee's signature field and your responsible.

The staff of the service provider has civil engineer, construction workers, cleaners and shipowner. Each employee received your PPE according to the activity to be performed, the protective equipment in common for all employees were uniforms, boots, safety helmets, gloves and sunscreen.

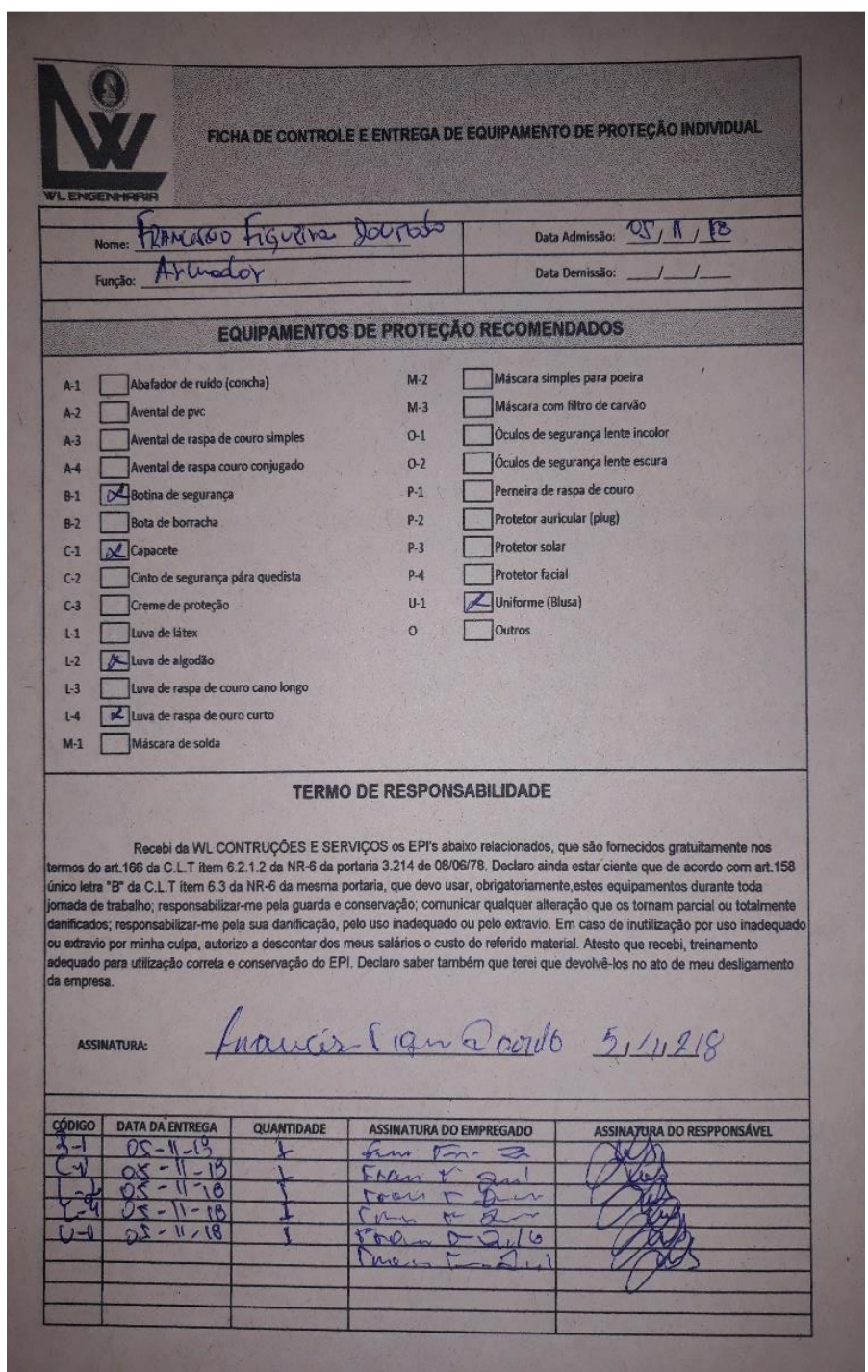

Figure 3: Control and Delivery Record of PPE. Source: Authors, (2019).

Figure 3 presents the record of personal protective equipment that was created and used by the service provider as requested by safety technician.

Safety technical guides start employees and managers at every step of the job, such as digging the ditch to insert the flanges of reinforced concrete has requested a report on stability of ditch, if the depth of the ditch was more than $1,25 \mathrm{~m}$ and in the construction of the wall led owners to put protection on the ends of the rods correctly, charged the use of personal protective equipment for employees, it was observed that the staff didn't want to use PPE' s correctly, not for lack of training, but not to feel comfortable in the use of the same, some said that the PPE's facing the execution of its activities, others claimed that the equipment were nonsense and trivialized using the same, however, the security technician charged so intense so that they use the protective equipment and at the same time informing what are the consequences if the officials stopped using the PPE's, making explicit that failure to use greatly increases the risk of accident at work endangering your health and that if the developer would continue insisting on not using PPE's would be prompted the shutdown.

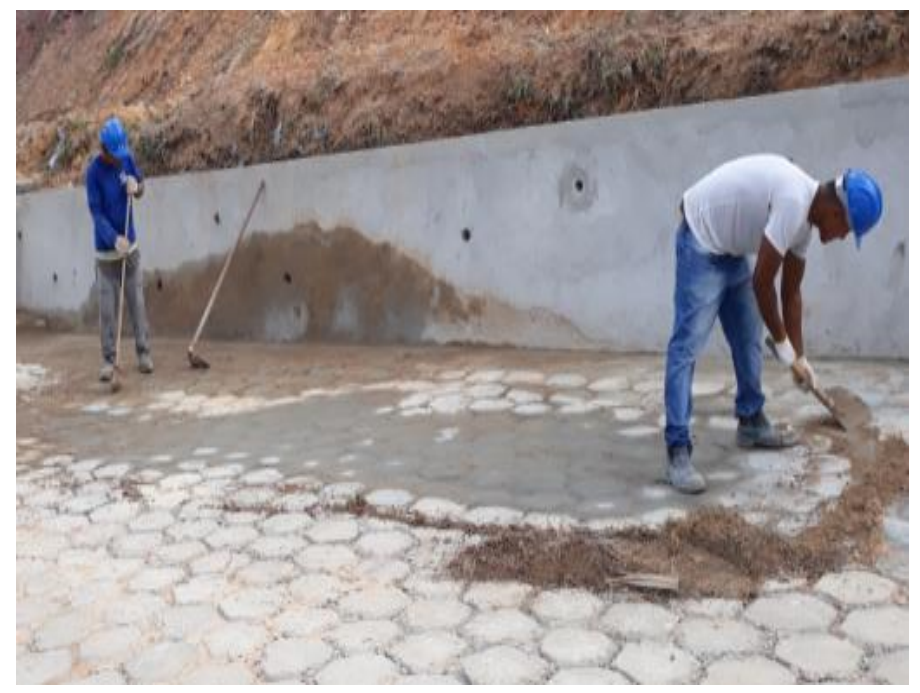

Figure 4: Staff using the PPE's.

Source: Authors, (2019).

Figure 4 presents two staff using the individual protection equipment, PPE' s are basic to any low-risk activity to be performed in construction such as: uniform, Boots, gloves and helmet safety.

\section{RESULTS AND DISCUSSION}

This study confirmed part of the results found in the literature. With regard to PPE, it may be noted that the use of individual protection equipment is extremely important, because at the end of the work there was no accident, although officials feel bothered by the use and then stop using the PPE' s, the coach was always security around inspecting the activities of employees.

In the civil construction market companies to comply with labor laws, most often provide PPE's, but does not maintain security professionals in your picture, favoring thus the risk of injury, so it is possible to confirm that without a safety professional at work risk of accident in construction site is high, because if I didn't have the intense collection of professional with broader knowledge in the management of documents and equipment, possibly something more serious would have happened, even the term of work being short and the amount of lower officials.

\section{CONCLUSIONS}

With the results obtained, it can be concluded that the use of personal protective equipment is the determining factor for the success of any company that seeks a good security management with a focus on minimizing the risks of accidents at work.

Employees are the most critical to prevent accidents at work, because they are at the tip of the executions of the labor activities, the company may have a security copy framework, however, if the employee does not cooperate in the use of personal protective equipment the risk of accident is enormous leading so failure in management and security. However, all parties have a huge responsibility for the safety of all workers, the company has 
obligation to provide personal protective equipment correctly and free of charge, providing a professional competent to supervise workers in the execution of its services and lastly as mentioning previously the employees must use PPE's as has the regulatory standard-NR 6.

An important suggestion for future work is that you can use search tools, such as a more detailed questionnaire with personal questions to workers about the main reason not to use the protective equipment and they are for your own protection.

\section{ACKNOWLEDGMENTS}

First the God who always blessed me of grand way, putting the angels in my life so I can accomplish my goals.

My father Luzinaldo Peixoto da Silva that with your unconditional love, lost nights of sleep, resigned for goals I could reach my, turned me into a man of character and success.

I thank the professionals who have contributed to the realization of this work and the Institute of higher education Blauro Cardoso de Mattos - FASERRA.

\section{REFERENCES}

[1] Padrão Regulamentar. NR 6: Equipamentos de Proteção Individual-PPE, 2006.

[2] Guia de Trabalho. Equipamentos de proteção individual de PPE - não apenas o fornecimento que você precisa supervisionar, 2019. Available

in: <http://www.guiatrabalhista.com.br/tematicas/PPE.htm>. Acesso em: 08 julho 2019.

[3] CISZ, Cleiton Rodrigo. Consciência do uso de ipês, segurança pessoal e coletiva. Conclusão do curso de monografia (Pósgraduação), Engenharia de segurança do trabalho, Universidade Federal Tecnológica do Paraná. Curitiba, 2015.

[4] Amaral, A. G. do. Segurança no trabalho: PPE em construção. Rev. Ciênc. Empresa. UNIPAR, Umuarama, v. 14, n. 2, p. 231257, jul./dez. 2013.

[5] Padrão Regulamentar. NR 4: Serviços Especializados em Engenharia de Segurança e Medicina Ocupacional (104.000-6).

[6] Um Congresso Nacional de Excelência em Gestão. Segurança no trabalho: motivo pelo qual o trabalhador da construção civil não utiliza PPEs. Agosto de 2015.

[7] Mônico, Aline. A importância do equipamento de proteção individual. Centro Universitário das Faculdades Metropolitanas Unidas. São Paulo.

[8] Pelloso, Eliza Fioravenante. Causas de resistência de equipamentos de proteção (PPE), 2012.

[9] Prates, Admilson Eustaquio. Uso de equipamentos de proteção individual por trabalhadores da construção civil. Revista Bionorte, v. 5, n. 2, jul. 2016. 